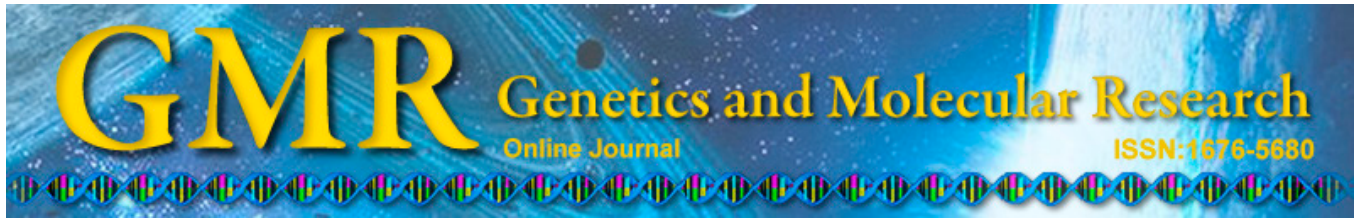

\title{
Effect of ethyl methyl sulfonate concentration and different treatment conditions on germination and seedling growth of the cucumber cultivar Chinese long (9930)
}

\author{
S.N.M. Shah ${ }^{1,2}$, Z.-H. Gong ${ }^{1}$, M.H. Arisha ${ }^{1,3}$, A. Khan ${ }^{1}$ and S.-L. Tian ${ }^{1,4}$ \\ ${ }^{1}$ College of Horticulture, Northwest A\&F University, Yangling, Shaanxi, China \\ ${ }^{2}$ Department of Horticulture, Faculty of Agriculture, \\ Gomal University, D.I. Khan, Pakistan \\ ${ }^{3}$ Horticulture Department, Faculty of Agriculture, Zagazig University, \\ Zagazig, Egypt \\ ${ }^{4}$ Department of Bioengineering, Huanghuai University, Henan, Zhumadian, \\ China
}

Corresponding author: Z.-H. Gong

E-mail: zhgong@nwsuaf.edu.cn

Genet. Mol. Res. 14 (1): 2440-2449 (2015)

Received November 10, 2014

Accepted March 10, 2015

Published March 30, 2015

DOI http://dx.doi.org/10.4238/2015.March.30.2

\begin{abstract}
We attempted to create a new germplasm of cucumber cultivar Chinese long (9930) using different doses of ethyl methyl sulfonate (EMS) to induce variability. We tested EMS concentration $(0$, $0.5,1.0,1.5,2,3 \% \mathrm{v} / \mathrm{v})$ with post-treatment $\left(0.1 \mathrm{M} \mathrm{Na}_{2} \mathrm{~S}_{2} \mathrm{O}_{3}\right.$ and water), EMS concentration $(0,0.5,1.0,1.5 \% \mathrm{v} / \mathrm{v})$ over different treatment times $(8,16,24 \mathrm{~h})$, and EMS concentration $(0,0.5,1.0,1.5 \% \mathrm{v} / \mathrm{v})$ with different treatment temperatures $\left(20\right.$ and $\left.28^{\circ} \mathrm{C}\right)$. In all experiments with increasing EMS concentration, germination percent, index, and rate were decreased. After addition of stop solution $\left(0.1 \mathrm{M} \mathrm{Na}_{2} \mathrm{~S}_{2} \mathrm{O}_{3}\right)$, posttreatment mutated seeds showed higher germination $(84.44 \%)$ and rate $(37.5 \%)$ than seeds treated with water ( 80 and $34.07 \%$, respectively),
\end{abstract}


while the germination index was high in seeds treated with water. At $20^{\circ} \mathrm{C}$, the germination index (4.13) and rate $(56.25 \%)$ were affected to a greater extent than at $28^{\circ} \mathrm{C}(7.68$ and $91.31 \%$, respectively). Treatment times of 16 and $24 \mathrm{~h}$ showed similar results for germination percent and rate, while the germination index was decreased over time. There were significant differences in seedling height, fresh true leaf weight, seedling weight, and plant survival with increasing EMS concentration and time. Higher variations in the form of dwarf seedlings were recorded after treatment with $1.5 \%$ EMS for $24 \mathrm{~h}$. Based on germination and morphological data, an EMS concentration of $1.5 \%$ for $24 \mathrm{~h}$ at $20^{\circ} \mathrm{C}$ and post-treatment with stop solution $\left(0.1 \mathrm{M} \mathrm{Na}_{2} \mathrm{~S}_{2} \mathrm{O}_{3}\right)$ efficiently caused mutation.

Key words: Breeding; Cucumber; Germination; Mutation; Seedlings; Weight

\section{INTRODUCTION}

Cucumber (Cucumis sativus) is a widely cultivated vegetable in temperate, subtropical, and tropical climates. Cucumber is one of the oldest and the 4th most cultivated vegetable worldwide. Thirty Cucumis species are present in Asia and Africa (Yawalkar, 1985), and are exposed to various biotic and abiotic stresses. Cucumber crops require genetic variability (induced mutation) to overcome biotic and abiotic hurdles, but this does not always occur naturally. Induced genetic variation has been used successfully in more than 100 plant species and many officially released (Maluszynski, 2001) varieties. Chemical [ethyl methyl sulfonate (EMS), methyl methanesulfonate, diethylsulfate, sodium azide, nitrous oxide] and physical (X-rays, $\gamma$-rays, UV radiation, fast and thermal neutrons, $\alpha$ and $\beta$ particles) mutagens have been widely used to induce a large number of functional variations in different plant species, as well as to generate new varieties with improved traits. Among the mutagenic agents used, EMS $\left(\mathrm{CH}_{3} \mathrm{SO}_{2} \mathrm{OC}_{2} \mathrm{H}_{5}\right)$ is very effective and efficient as well as the most widely used chemical mutagen for inducing mutations (Van Harten, 1998; Kodym and Afza, 2003). EMS generates random mutations throughout the genome (Greene et al., 2003). However, a crucial requirement in mutation induction is the selection of an efficient and optimum dose of mutagenic agent. Few studies have examined EMS doses in different crop species/cultivars. The efficiency of EMS not only depends on EMS quality but also on genotype (Kodym and Afza, 2003). Many other factors also affect mutagen effectiveness and efficiency, such as mutagen properties, treatment time, pre- and post-treatments, $\mathrm{pH}$, and temperature (Roychowdhury and Tah, 2011). The resistance level of biological materials to a mutagen can be observed in the $\mathrm{M}_{1}$ generation by measuring germination and lethality (Gaul, 1970). Another fast and simple method is determining seedling injury (reduction in seedling height, root length, survival) under greenhouse conditions to evaluate the effect of EMS. In this study, we examined different conditions, including post-treatment, temperature during EMS reactions and treatment time to evaluate the effect of EMS in generating optimum variations in cucumber to create new germplasms. 


\section{MATERIAL AND METHODS}

\section{Plant material}

The cucumber cultivar Chinese long (Line 9930) was used in this study as plant material. The seeds were provided by the Cucumber Research Group, Collage of Horticulture, Northwest A\&F University, China. Experiments were performed from August to November 2013.

\section{EMS concentration and post-treatment}

Seeds were presoaked in distilled water for $10 \mathrm{~h}$. Next, the seeds were transferred to $0.1 \mathrm{M}$ buffer $\left(1: 1 \mathrm{Na}_{2} \mathrm{HPO}_{4}+\mathrm{NaH}_{2} \mathrm{PO}_{4}\right), \mathrm{pH} 7.0$, and various concentrations of EMS were added $(0,0.5,1.0,1.5,2,3 \% \mathrm{v} / \mathrm{v})$. The seeds were then placed in a rotary shaker at $100 \mathrm{rpm}$ at $20^{\circ} \mathrm{C}$ for $24 \mathrm{~h}$. The seeds were post-treated with stop solution $\left(0.1 \mathrm{M} \mathrm{Na}_{2} \mathrm{~S}_{2} \mathrm{O}_{3}\right)$ and water. For stop solution treatment, the seeds were washed 3 times (fresh) and then incubated for 15 min in fresh solution, followed by thorough washing with running water further for $15 \mathrm{~min}$. For water treatment, the seeds were washed with running water for the same amount of time as used in the stop solution treatment.

\section{EMS concentration and treatment temperature}

Seeds were presoaked in distilled water for $10 \mathrm{~h}$. Next, the seeds were transferred to $0.1 \mathrm{M}$ buffer $\left(1: 1 \mathrm{Na}_{2} \mathrm{HPO}_{4}+\mathrm{NaH}_{2} \mathrm{PO}_{4}\right), \mathrm{pH} 7.0$, and various concentrations of EMS were added $(0,0.5,1.0,1.5 \% \mathrm{v} / \mathrm{v})$. The seeds were then placed in a rotary shaker $(100 \mathrm{rpm})$ at 2 different temperatures, including 20 and $28^{\circ} \mathrm{C}$, for different times over $24 \mathrm{~h}$. The seeds treated were washed 3 times with stop solution and then transferred to fresh stop solution for $15 \mathrm{~min}$. The seeds were then thoroughly washed with running water for $15 \mathrm{~min}$.

\section{EMS concentration and treatment time}

Seeds were presoaked in distilled water for $10 \mathrm{~h}$. Next, the seeds were transferred to $0.1 \mathrm{M}$ buffer $\left(1: 1 \mathrm{Na}_{2} \mathrm{HPO}_{4}+\mathrm{NaH}_{2} \mathrm{PO}_{4}\right)$ solution, $\mathrm{pH} 7.0$, and various concentrations of EMS were added $(0,0.5,1.0,1.5 \% \mathrm{v} / \mathrm{v})$. The seeds were then placed in a rotary shaker $(100 \mathrm{rpm})$ at $28^{\circ} \mathrm{C}$ for different times $(8,16$, and $24 \mathrm{~h})$. The seeds treated were washed 3 times with stop solution and then transferred to fresh stop solution for $15 \mathrm{~min}$. The seeds were thoroughly washed with running water for $15 \mathrm{~min}$.

\section{Germination}

The seeds for all experiments were transferred to 9-cm Petri dishes on 4 layers of filter paper, which had been moistened with distilled water. Petri dishes were placed at $26 \pm$ $2^{\circ} \mathrm{C}$ under a $16: 8 \mathrm{~h}$ photoperiod in an incubator (Farooq et al., 2008) until radical emergence.

Seeds with visible radicals were considered to be germinated on the Petri dish. 

equations.

The data regarding germination parameters were recorded according to the following

$$
\begin{gathered}
\text { Germination }(\%)=\frac{\text { No.of Seeds Germinated }}{\text { Total No. of Seeds Sown }} \times 100 \quad \text { (Equation 1) } \\
\text { Germination Index }(G I)=\frac{\text { No.of germinated seed }}{\text { Days of First Count }}+\cdots+\frac{\text { No.of germinated seed }}{\text { Days of Final Count }} \quad \text { (Equation 2) } \\
\text { Germination Speed }(\%)=\frac{\text { No. of Seeds Germinated at First Count }}{\text { No. of Seeds Germinated at Final Count }} \times 100
\end{gathered}
$$

The germinated seeds in experiments testing EMS concentration and treatment time with the prominent radical were planted in growing trays (compost) to confirm the biological effects of EMS on cucumber seedlings. The data were recorded 3 weeks after planting in growing trays at the 2 to 3 true leaf stage. Seedling height $(\mathrm{cm})$, dwarf and tall, fresh true leaf weight $(\mathrm{g})$, seedling weight $(\mathrm{g})$, root length $(\mathrm{cm})$, and seedling survival $(\%)$ were determined.

\section{Design and analysis}

Experiments were designed in a completely randomized block design with 2 factors; experiments were conducted 3 times. Data were analyzed statistically using Statistix 8.1 (Analytical Software, Tallahassee, FL, USA) and the least significant difference $(\mathrm{P}<0.05)$ test was used to identify significant differences among treatments.

\section{RESULTS AND DISCUSSION}

\section{Germination (\%), germination index (GI), and germination speed (GS) (\%)}

\section{EMS concentration and post-treatment}

Statistical analysis revealed that the germination (\%), GI, and GS of cucumber seeds was significantly $(\mathrm{P}<0.05)$ affected by EMS concentration and post-treatment, and their interaction were also significant (Table 1). Seed germination (\%) was not significantly affected at the $0,0.5$, and $1 \%$ EMS concentrations, but then sharply decreased at the 1.5 to $3 \%$ EMS levels. A high germination percent $(84.44 \%$ ) was recorded following post-treatment with stop solution compared to treatment with water $(80 \%)$. For the combined effect of EMS and posttreatment, stop solution $\left(0.1 \mathrm{M} \mathrm{Na}_{2} \mathrm{~S}_{2} \mathrm{O}_{3}\right)$ treatment resulted in higher germination than water treatment at 3\% EMS, while at 2\% EMS, the seeds treated with water showed higher germination (Figure 1A). This may be because the stop solution $\left(\mathrm{Na}_{2} \mathrm{~S}_{2} \mathrm{O}_{3}\right)$ stopped the EMS reaction from further damaging the embryo, while at $2 \%$ EMS, seeds that had been post-treated with water may have contained small amounts of mutagen in the embryo, increasing seed viability. A higher germination index (6.17) was recorded in control seeds but lower rate (0.44) with 
3\% EMS. Post-treatment of mutated seeds with water (3.49) resulted in a higher germination index than treatment with stop solution (2.97). The interaction graph showed that treatment of seeds with stop solution $\left(\mathrm{Na}_{2} \mathrm{~S}_{2} \mathrm{O}_{3}\right)$ caused the seeds to be more vigorous at 0.5 and $1.5 \%$ EMS compared to water treatment, while the stop solution $\left(\mathrm{Na}_{2} \mathrm{~S}_{2} \mathrm{O}_{3}\right)$-treated seeds showed decreased its vitality at 0,1 , and $2 \%$ compared to water treatment (Figure 1B). A higher germination rate $(95 \%)$ was observed in control seeds than in seeds treated with $1.5 \%$ EMS $(12.5 \%)$, while no seeds germinated at 2 and 3\% EMS. The seeds that had been post-treated with stop solution $(37.5 \%)$ quickly germinated compared to germination in water $(34.07 \%)$. Cucumber germination speed sharply decreased with increasing EMS concentration (Figure 1C). The reduction or slowing of cucumber seed germination with increased EMS dose may have been caused by a delay or inhibition of physiological processes such as enzyme activity, hormonal imbalance, and inhibition of mitotic process (Kumar and Gupta, 2009; Devi and Mullainathan, 2011; Borovsky et al., 2013). Previous studies in different crops have shown that decreased germination indicates the effectiveness of mutagenic agents (Bahar and Akkaya, 2009). Our results also revealed that post-treatment of mutated seeds with water and stop solution at each level of EMS had different effects on seeds.

Table 1. Effect of EMS levels and post-treatment on germination percent, index, and speed of cucumber cultivar Chinese long (9930) at $20^{\circ} \mathrm{C}$ in $\mathrm{M}_{1}$ generation.

\begin{tabular}{llccc}
\hline Treatments & Treatments levels & Germination $(\%)$ & Germination index & Germination speed $(\%)$ \\
\hline EMS conc. $(\%)$ & 0 & $100.00^{\mathrm{a}}$ & $6.17^{\mathrm{a}}$ & $95.00^{\mathrm{a}}$ \\
& 0.5 & $100.00^{\mathrm{a}}$ & $4.96^{\mathrm{b}}$ & $75.00^{\mathrm{b}}$ \\
& 1.0 & $100.00^{\mathrm{a}}$ & $3.85^{\mathrm{c}}$ & $32.22^{\mathrm{c}}$ \\
& 1.5 & $83.33^{\mathrm{b}}$ & $2.99^{\mathrm{d}}$ & $0.00^{\mathrm{e}}$ \\
& 2 & $70.00^{\mathrm{c}}$ & $0.97^{\mathrm{e}}$ & $0.00^{\mathrm{e}}$ \\
LSD value $(\mathrm{P} \leq 0.05)$ & 3 & $40.00^{\mathrm{d}}$ & 0.23 & 2.1250 \\
Post-treatment & Water & 8.843 & $3.49^{\mathrm{a}}$ & $34.07^{\mathrm{b}}$ \\
LSD value $(\mathrm{P} \leq 0.05)$ & Stop solution & $80.00^{\mathrm{b}}$ & $2.97^{\mathrm{b}}$ & $37.50^{\mathrm{a}}$ \\
Interaction $(\mathrm{P} \leq 0.05)$ & & $84.44^{\mathrm{a}}$ & 0.1328 & 1.2269 \\
\hline
\end{tabular}

* Significant difference at $\mathrm{P}<0.05$. Means with different lower case letters are significantly different at $\mathrm{P}<0.05$.

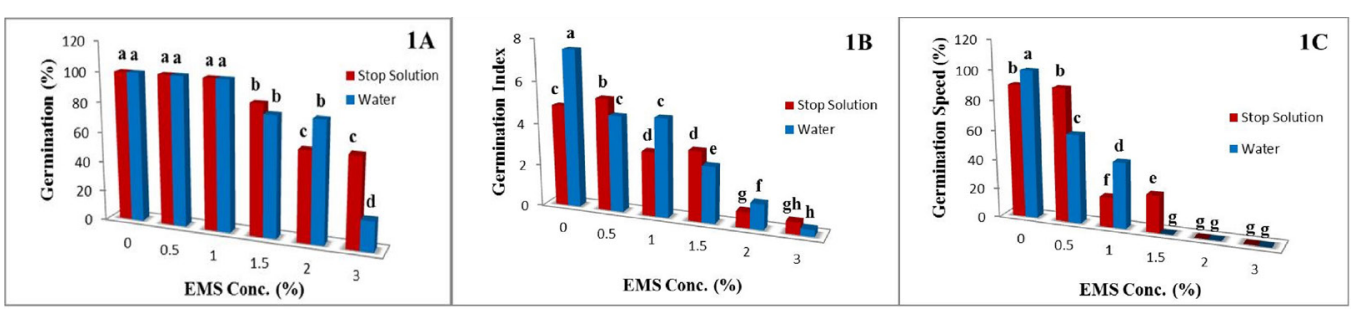

Figure 1. Effect of EMS concentration and post-treatment on the germination percent $(\mathbf{1 A})$, germination index (1B), and germination speed (1C). The results represent the mean from three independent biological replicates. Bars with different lower case letters indicate significant differences using least significant differences $(\mathrm{P}<0.05)$.

\section{EMS concentration and treatment temperature}

The influence of EMS concentration, treatment temperature, and their interaction was significant for percent (EMS levels) GI and GS, while germination percent for the temperature factor and the interaction with EMS levels was non-significant (Table 2). The germination 
percent, GI, and GS of the cucumber seeds decreased with increasing EMS concentration, while at $20^{\circ} \mathrm{C}$, EMS caused more damage to the seed embryo. Seeds treated with EMS at $20^{\circ} \mathrm{C}$ showed severe damaged, compared to treatment at $28^{\circ} \mathrm{C}$ by affecting GS and GI (Figure $2 \mathrm{~A}$ and $\mathrm{B})$. Temperature is an important factor during the mutagenic reaction. The half-life of EMS decreases with increasing temperature (Kodym and Afza, 2003), and thus EMS is more effective at a lower temperature $\left(20^{\circ} \mathrm{C}\right)$.

Table 2. Effect of EMS levels and treatment temperature on germination percent, index, and speed of cucumber cultivar Chinese long (9930) in $\mathrm{M}_{1}$ generation.

\begin{tabular}{|c|c|c|c|c|}
\hline Treatments & Treatments levels & Germination (\%) & Germination index & Germination speed (\%) \\
\hline \multirow[t]{4}{*}{ EMS conc. $(\%)$} & 0 & $100^{\mathrm{a}}$ & $7.19^{\mathrm{a}}$ & $93.33^{\mathrm{a}}$ \\
\hline & 0.5 & $99.11^{\mathrm{a}}$ & $6.45^{\mathrm{b}}$ & $89.81^{\mathrm{b}}$ \\
\hline & 1.0 & $97.61^{\mathrm{a}}$ & $5.05^{\mathrm{c}}$ & $60.60^{\mathrm{c}}$ \\
\hline & 1.5 & $88.33^{\mathrm{b}}$ & $4.96^{\mathrm{c}}$ & $51.38^{\mathrm{d}}$ \\
\hline \multirow[t]{2}{*}{ LSD value $(\mathrm{P}<0.05)$} & & 6.9295 & & \\
\hline & 0.5138 & 2.4956 & & \\
\hline \multirow[t]{2}{*}{ Temperature } & $20^{\circ} \mathrm{C}$ & 96.67 & $4.13^{\mathrm{b}}$ & $56.25^{\mathrm{b}}$ \\
\hline & $28^{\circ} \mathrm{C}$ & 95.86 & $7.68^{a}$ & $91.31^{\mathrm{a}}$ \\
\hline LSD value $(\mathrm{P}<0.05)$ & & NS & 0.3633 & 1.7647 \\
\hline Interaction $(\mathrm{P}<0.05)$ & & NS & Figure $3 A^{*}$ & Figure $3 B^{*}$ \\
\hline
\end{tabular}

*Significant difference at $\mathrm{P}<0.05$. Means with different lower case letters are significantly different at $\mathrm{P}<0.05$.

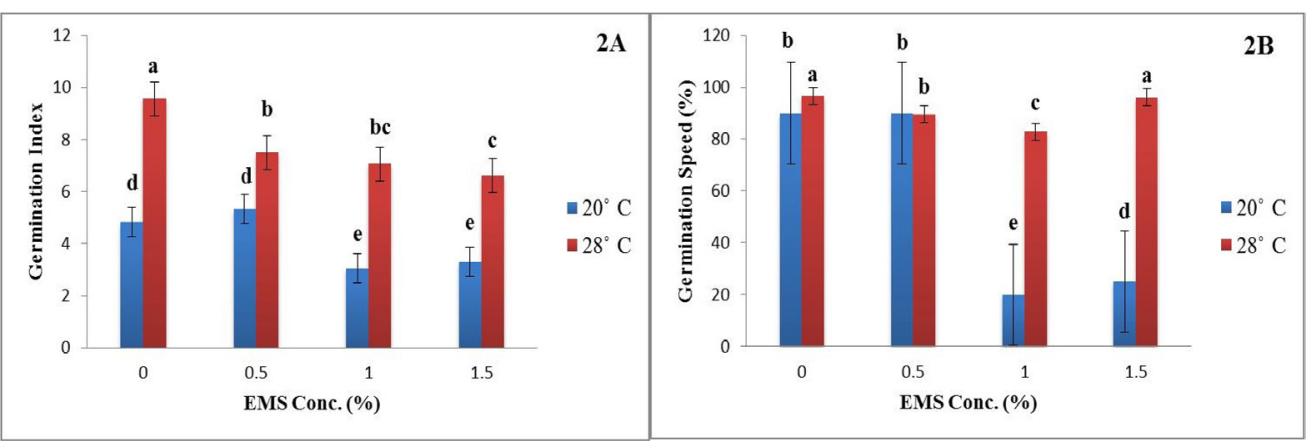

Figure 2. Effect of EMS concentration and treatment temperature on germination index $(\mathbf{2 A})$ and germination speed (2B). Results are reported as means \pm SE from three independent biological replicates. Bars with different lower case letters indicate significant differences using least significant differences $(\mathrm{P}<0.05)$.

\section{EMS concentration and treatment time}

Our results showed that EMS significantly $(\mathrm{P}<0.05)$ affected germination $(\%)$, GI, and GS (\%) of cucumber seeds (Table 3). Increased EMS concentration and treatment time decreased cucumber seed germination. Cucumber seed germination decreased with increasing EMS concentration, while treatment time at 1.5\% EMS contrasted with respect to other treatments (Figure $3 \mathrm{~A})$. The germination of cucumber seeds was less affected at $8 \mathrm{~h}$ of treatment compared to 16 and $24 \mathrm{~h}$ of treatment. Germination after $16 \mathrm{~h}$ treatment was lower than after $24 \mathrm{~h}$ in the presence of $1.5 \%$ EMS. Increased treatment time may allow for seed hydration, which may facilitate the uptake of mutagen and improve the metabolic activity of cells as well as initiation and DNA synthesis in the growing embryo (Natarajan and Shivasankar, 1965; Seetharami and Prabhakar, 1983), leading to higher germination. A higher GI was recorded at $8 \mathrm{~h}$ and $0 \%$ EMS-treated seeds 
(9.69 and 9.57, respectively), while GI was lower in seeds treated for $24 \mathrm{~h}$ with $1.5 \%$ EMS (7.68 and 7.82, respectively). In the interactive treatments, a higher GI was observed after 16-h treatment with 1\% EMS, while a lower GI was observed following treatment with $1.5 \%$ EMS for $16 \mathrm{~h}$ (Figure 3B). Comparison of GI after different treatments revealed that treatment time and EMS concentration greatly affected seeds vigorousness. Plant growth and seed vigor decreased with increasing EMS concentration (Sharma and Kumar, 2003), indicating the effectiveness and efficiency of EMS. Control seeds germinated faster than EMS-treated seeds and GS decreased with increasing treatment time (Table 3). Seeds treated with 1 and 1.5\% EMS for $8 \mathrm{~h}$ showed similar rates compared to control seeds (Figure 3C). At each EMS level, the 24-h treatment time resulted in a longer time to germinate compared to other treatment times.

\begin{tabular}{|c|c|c|c|c|}
\hline Treatments & Treatments levels & Germination (\%) & Germination index & Germination speed (\%) \\
\hline \multirow[t]{4}{*}{ EMS conc. (\%) } & 0 & $100^{\mathrm{a}}$ & $9.57^{\mathrm{a}}$ & $97.22^{\mathrm{a}}$ \\
\hline & 0.5 & $99.41^{\mathrm{ab}}$ & $8.93^{\mathrm{b}}$ & $95.43^{\mathrm{b}}$ \\
\hline & 1.0 & $97.19^{\mathrm{b}}$ & $8.48^{\mathrm{c}}$ & $94.73^{b}$ \\
\hline & 1.5 & $90.26^{\mathrm{c}}$ & $7.82^{\mathrm{d}}$ & $87.59^{\mathrm{c}}$ \\
\hline LSD value $(\mathrm{P}<0.05)$ & & 2.2379 & 0.3911 & 0.9345 \\
\hline \multirow[t]{3}{*}{ Time } & $8 \mathrm{~h}$ & $99.083^{\mathrm{a}}$ & $9.69^{\mathrm{a}}$ & $99.33^{\mathrm{a}}$ \\
\hline & $16 \mathrm{~h}$ & $95.194^{\mathrm{b}}$ & $8.71^{\mathrm{b}}$ & $91.31^{\mathrm{b}}$ \\
\hline & $24 \mathrm{~h}$ & $95.862^{b}$ & $7.68^{\mathrm{c}}$ & $90.58^{\mathrm{b}}$ \\
\hline LSD value $(\mathrm{P}<0.05)$ & & 1.9381 & 0.3387 & 0.8093 \\
\hline Interaction $(\mathrm{P}<0.05)$ & & Figure $2 A^{*}$ & Figure $2 \mathrm{~B}^{*}$ & Figure $2 \mathrm{C}^{*}$ \\
\hline
\end{tabular}

*Significant difference at $\mathrm{P}<0.05$. Means with different lower case letters are significantly different at $\mathrm{P}<0.05$.

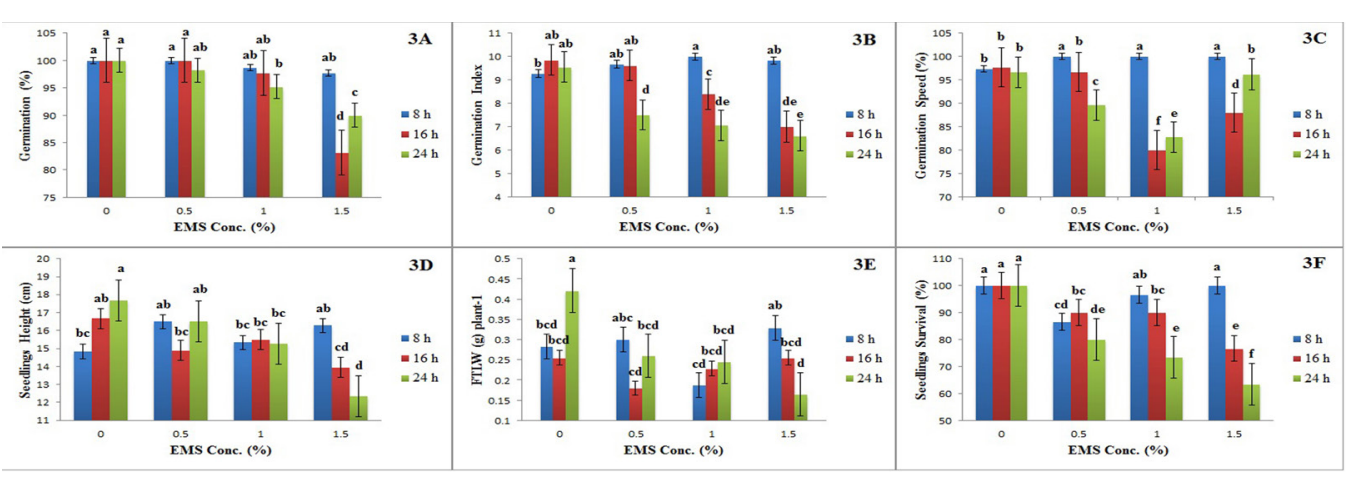

Figure 3. Effects of EMS concentration and time on germination percent (3A), germination Index (3B), germination speed (3C), seedling height (3D), fresh true leaf weight (3E), and seedling survival (3F). The results are reported as means \pm SE from three independent biological replicates. Bars with different lower case letters indicate differences using least significant differences $(\mathrm{P}<0.05)$.

\section{Seedling height $(\mathrm{cm})$, fresh true leaf weight $(\mathrm{g})$, seedling weight $(\mathrm{g})$, root length $(\mathrm{cm})$, and seedling survival (\%) after EMS treatment and varying treatment times}

The data regarding cucumber seedling height, fresh true leaf weight, seedling weight, root length, and survival are presented in Table 4. Changes in cucumber seedling height, seedling weight, root length, and survival were significant $(\mathrm{P}<0.05)$, while fresh true leaf weight $($ FTLW) was non-significantly $(\mathrm{P}<0.05)$ affected by EMS levels. Changes in seedling weight 
and survival were significant $(\mathrm{P}<0.05)$, while seedling height, FTLW, and root length were non-significantly $(\mathrm{P}<0.05)$ affected by time. The lowest seedling height $(14.19 \mathrm{~cm})$, seedling weight $(1.13 \mathrm{~g})$, root length $(3.49 \mathrm{~cm})$, and survival $(80 \%)$ were observed following treatment with $1.5 \%$ EMS, while the highest seedling height $(16.39 \mathrm{~cm})$, seedling weight $(1.46 \mathrm{~g})$, root length $(6.22 \mathrm{~cm})$, and survival $(100 \%)$ were observed in controls. Seedling height can be used to indicate the biological effect of EMS (Jabeen and Mirza, 2004). A previous study showed that an increased dose of EMS reduced plant height (Deepalakshmi and Anandakumar, 2004). Interestingly, the maximum weight $(1.3 \mathrm{~g})$ of cucumber seedlings was recorded in the $24-\mathrm{h}$ treatment group compared to the $8 \mathrm{~h}$ treatment $(1.28 \mathrm{~g})$. The tallest $(\sim 96 \%)$ seedlings survived after treatment for $8 \mathrm{~h}$, but the height was lower $(\sim 79 \%)$ in the 24 -h treatment group. The association between EMS and time showed significant $(\mathrm{P}<0.05)$ results for seedling height, FTLW, and survival, but non-significant $(\mathrm{P}<0.05)$ for seedling weight and root length (Table 4). We observed an inconsistent trend in seedling height for all EMS levels at 8 and $16 \mathrm{~h}$, while at $24 \mathrm{~h}$, a decreasing trend was observed at all EMS levels (Figure 3D). With respect to time, the 1\% EMS concentration resulted in uniform seedling height. The lowest FTLW/ plant $(0.17 \mathrm{~g})$ was observed in cucumber plants whose seeds were treated with $1.5 \%$ EMS for $24 \mathrm{~h}$, while this value was higher in the control (Figure 3E). FTLW/plant was nearly uniform following 1\% EMS for all treatment times. The $24 \mathrm{~h}$ treatments showed a decreasing trend with respect to EMS concentration, while the 8 and $16 \mathrm{~h}$ groups showed inconsistent results. For the combined effect of EMS and time, cucumber seedling survival (\%) decreased with increasing EMS concentration (Figure 3F). Minimum seedling survival (63.33\%) was following $24 \mathrm{~h}$ treatment with $1.5 \%$ EMS, while the maximum (100\%) value was observed in the control treatments as well as 1.5\% EMS for $8 \mathrm{~h}$. Figure 3F shows a decreasing trend for the 24 and $16 \mathrm{~h}$ treatments, but for $8 \mathrm{~h}$ treatment, values decreased and then increased with respect to EMS concentration. Mutagenic effectiveness and efficiency is calculated based on the biological damage (i.e. reduction in plant growth parameters) and decreased with increasing doses or concentrations of mutagen (Thilagavathi and Mullainathan, 2009). Our results agree with those of a previous study (Roychowdhury and Tah, 2011) which demonstrated that with increasing EMS levels, germination and survivability decreased.

Table 4. Effect of EMS levels and treatment time on seedling height $(\mathrm{cm})$, Fresh true leaf weight $(\mathrm{g})$, seedling weight (g), and seedling survival (\%) of cucumber cultivar Chinese long (9930) at $28^{\circ} \mathrm{C}$ in $\mathrm{M}_{1}$ generation.

\begin{tabular}{|c|c|c|c|c|c|c|}
\hline Treatments & Levels & Seedling height $(\mathrm{cm})$ & FTLW (g) & Seedling weight (g) & Root length $(\mathrm{cm})$ & Plant survival (\%) \\
\hline \multirow[t]{4}{*}{ EMS conc. (\%) } & 0 & $16.39^{\mathrm{a}}$ & 0.32 & $1.46^{\mathrm{a}}$ & $6.22^{\mathrm{a}}$ & $100^{\mathrm{a}}$ \\
\hline & 0.5 & $15.96^{\mathrm{a}}$ & 0.25 & $1.17^{b}$ & $4.09^{b}$ & $86.67^{b}$ \\
\hline & 1.0 & $15.37^{\mathrm{ab}}$ & 0.22 & $1.13^{\mathrm{b}}$ & $3.58^{b}$ & $85.56^{\mathrm{b}}$ \\
\hline & 1.5 & $14.19^{b}$ & 0.25 & $1.13^{\mathrm{b}}$ & $3.49^{\mathrm{b}}$ & $80.00^{\mathrm{c}}$ \\
\hline LSD value $(\mathrm{P} \leq 0.05)$ & & 1.21 & NS & 0.19 & 1.28 & 5.22 \\
\hline \multirow[t]{3}{*}{ Time (Hours) } & 8 & 15.74 & 0.28 & $1.28^{\mathrm{a}}$ & 4.65 & $95.83^{\mathrm{a}}$ \\
\hline & 16 & 15.44 & 0.23 & $1.08^{\mathrm{b}}$ & 4.21 & $89.17^{\mathrm{b}}$ \\
\hline & 24 & 15.25 & 0.27 & $1.30^{\mathrm{a}}$ & 4.18 & $79.17^{\mathrm{c}}$ \\
\hline LSD value $(\mathrm{P} \leq 0.05)$ & & NS & NS & 0.17 & NS & 4.52 \\
\hline Interaction $(\mathrm{P} \leq 0.05)$ & & Figure $2 D^{*}$ & Figure $2 \mathrm{E}^{*}$ & NS & NS & Figure $2 \mathrm{~F}^{*}$ \\
\hline
\end{tabular}

*Significant difference at $\mathrm{P}<0.05$. Means with different lower case letters are significantly different at $\mathrm{P}<0.05$.

\section{Dwarf and tall seedlings}

The total number of dwarf and tall seedlings were recorded in all replications for each 
treatment (Table 5). The dwarf and tall plants were compared with control plants, and a 1-cm margin was used for comparison to minimize error. The plant height range in control treatment was $14.5 \mathrm{~cm}$ to $18.5 \mathrm{~cm}$ from dwarf to tall (Figure 4A). The 1\% EMS treatment for $16 \mathrm{~h}$ and $0.5 \%$ EMS treatment for $24 \mathrm{~h}$ produced the tallest seedlings, which were $20 \mathrm{~cm}$ tall (Figure $4 \mathrm{~B}$ and $\mathrm{C}$ ), while $1.5 \%$ EMS treatment for $16 \mathrm{~h}$ and $1.5 \%$ EMS treatment for $24 \mathrm{~h}$ resulted in dwarfed seedlings that were 4 and $4.3 \mathrm{~cm}$ tall, respectively (Figure 4D and E). Other dwarfed seedlings were greater than $4.3 \mathrm{~cm}$ and lower than $14 \mathrm{~cm}$, while tall seedlings were greater than $19 \mathrm{~cm}$ in height. This may be because of the effect of the mutagen on the meristematic tissues of the seeds (Roychowdhury and Tah, 2011), which led to changes in normal physiological processes and in chromosomes (Nilan et al., 1976; Singh and Kole, 2005), as well as delayed or early onset of mitosis (Yadav, 1987). Additionally, growth promoters may have increased or growth inhibitors may have been non-functional, or auxin levels may have been decreased (Roychowdhury and Tah, 2011).

Table 5. Number/percent of cucumber seedlings in response to EMS concentration and time in $\mathrm{M}_{1}$ generation.

\begin{tabular}{|c|c|c|c|c|c|c|}
\hline EMS (\%) & Time $(\mathrm{h})$ & Total No. of plants & No. of dwarfs & $\%$ of dwarfs & No. of tall seedlings & $\%$ of tall seedlings \\
\hline 0 & $8,16,24$ & 30 & - & - & - & - \\
\hline \multirow[t]{3}{*}{0.5} & 8 & 30 & 1 & 3.33 & 0 & 0 \\
\hline & 16 & 30 & 3 & 10 & 0 & 0 \\
\hline & 24 & 30 & 2 & 6.66 & 1 & 3.33 \\
\hline \multirow[t]{3}{*}{1} & 8 & 30 & 0 & 0 & 0 & 0 \\
\hline & 16 & 30 & 2 & 6.66 & 1 & 3.33 \\
\hline & 24 & 30 & 3 & 10 & 0 & 0 \\
\hline \multirow[t]{3}{*}{1.5} & 8 & 30 & 2 & 6.66 & 1 & 3.33 \\
\hline & 16 & 30 & 2 & 6.66 & 0 & 0 \\
\hline & 24 & 30 & 7 & 23.33 & 0 & 0 \\
\hline
\end{tabular}

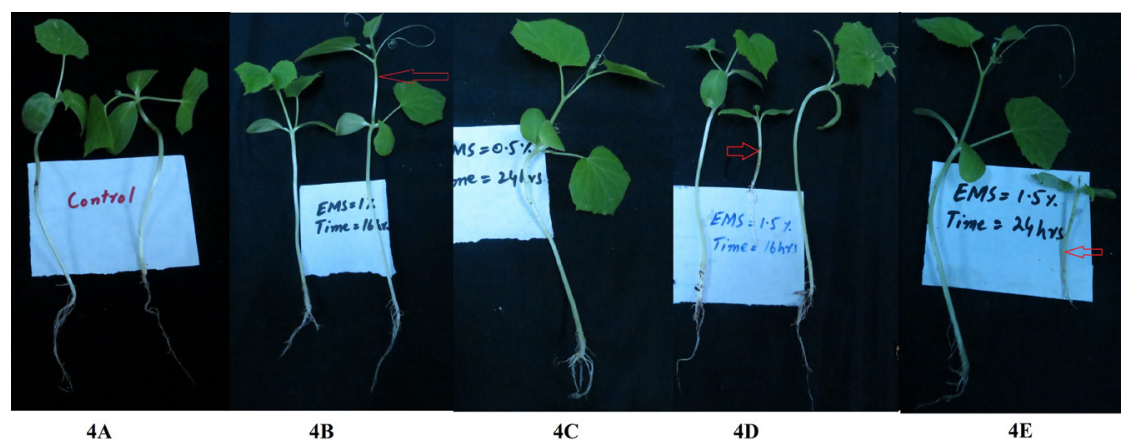

Figure 4. Dwarfed and tall cucumber seedlings, (4A) normal/control plants (4B and 4C). The 20-cm tall seedlings produced by treatments with $1 \% \mathrm{EMS}+16 \mathrm{~h}$ and $0.5 \% \mathrm{EMS}+24 \mathrm{~h}(\mathbf{4 D})$. The $4-\mathrm{cm}$ dwarfed seedling (middle) was observed following treatment with $1.5 \% \mathrm{EMS}+16 \mathrm{~h}$. The left and right images show mutated seedlings of normal height. (4E). The right seedling was $4.3 \mathrm{~cm}$ tall and the left seedling was $18.5 \mathrm{~cm}$ tall after treatment with $1.5 \% \mathrm{EMS}+24 \mathrm{~h}$.

\section{CONCLUSIONS}

In this study, we determined the biological effect of different concentrations of EMS and different environmental conditions on the cucumber cultivar $9930 \mathrm{M}_{1}$ generation and its sensitivity to mutagen. We found that the mutagenic effect on various germination behaviors such as germination percent, GI, GS, and growth characteristics including seedling height, 
true leaf weight, seedling weight, root length, and survivability following treatment with $1.5 \%$ EMS for $24 \mathrm{~h}$ was strong and induced a large amount of variation. Seeds that had been posttreated with water showed a high GI, and quickly germinated following post-treatment with stop solution $\left(0.1 \mathrm{M} \mathrm{Na}_{2} \mathrm{~S}_{2} \mathrm{O}_{3}\right)$. The analysis of the germination data with respect to temperature showed that EMS was more effective at $20^{\circ} \mathrm{C}$ than at $28^{\circ} \mathrm{C}$.

\section{ACKNOWLEDGMENTS}

Research supported by the National Natural Science Foundation of China (\#31272163) and the Shaanxi Provincial Science and Technology Coordinating Innovative Engineering Project (\#2012KTCL02-09).

\section{REFERENCES}

Bahar B and Akkaya MS (2009). Effects of EMS treatment on the seed germination in wheat. J. Appl. Biol. Sci. 3: 59-64. Borovsky Y, Tadmor Y, Bar E, Meir A, et al. (2013). Induced mutation in $\beta$-carotene hydroxylase results in accumulation of $\beta$-carotene and conversion of red to orange color in pepper fruit. Theor. Appl. Genet. 126: 557-565.

Deepalakshmi A and Anandakumar C (2004). Creation of genetic variability for different polygenic traits in black gram [Vigna mungo (L.) Hepper] through induced mutagenesis. Legume Res. 3: 188-192.

Devi AS and Mullainathan L (2011). Physical and chemical mutagenesis for improvement of chilli (Capsicum annuum L.). World Appl. Sci. J. 15: 108-113.

Farooq M, Basra S, Rehman H and Saleem B (2008). Seed priming enhances the performance of late sown wheat (Triticum aestivum L.) by improving chilling tolerance. J. Agron. Crop Sci. 194: 55-60.

Gaul H (1970). Plant injury and lethality. In: Manual on mutation breeding. Technical Report Series, Geneva, Switzerland, 85-90.

Greene EA, Codomo CA, Taylor NE, Henikoff JG, et al. (2003). Spectrum of chemically induced mutations from a largescale reverse-genetic screen in Arabidopsis. Genetics 164: 731-740.

Jabeen N and Mirza B (2004). Ethyl methane sulfonate induces morphological mutations in Capsicum annuum. Inter. J. Agric. Biol. 6: 340-435

Kodym A and Afza R (2003). Physical and chemical mutagenesis. In: Plant Functional Genomics. Springer, New York, 189-203.

Kumar G and Gupta P (2009). Induced karyomorphological variations in three phenodeviants of Capsicum annuum L. Turk. J. Bio. 33: 123-128.

Maluszynski M (2001). Officially released mutant varieties-the FAO/IAEA Database. Plant Cell Tiss. Org. 65: 175-177.

Natarajan A and Shivasankar G (1965). Studies on modification of mutation response of barley seeds to ethyl methanesulfonate. Z. Vererbungsl. 96: 13-21.

Nilan R, Kleinhofs A and Sander C (1976). Azide mutagenesis in barley. In: Barley Genetics III (H. Gaul, eds.). Karl Thiemig, Munich, pp. 113-122.

Roychowdhury R and Tah J (2011). Germination behaviors in M2 generation of Dianthus after chemical mutagenesis. Interl. J. Advan. Sci. Tech. Res. 1: 448-154.

Seetharami Reddi TV and Prabhakar G (1983). Azide induced chlorophyll mutants in grain Sorghum varieties. Theor. Appl. Genet. 64: 147-149.

Sharma V and Kumar G (2003). EMS induced viable macromutants in Cicer arietinum L. J. Cytol. Genet. 4: 85-89.

Singh R and Kole C (2005). Effect of mutagenic treatment with EMS on germination and some seedling parameters in mungbean. Crop Res. 30: 236-240.

Thilagavathi C and Mullainathan L (2009). Isolation of macro mutants and mutagenic effectiveness, efficiency in black gram [Vigna mungo (L.) Hepper]. Global J. Mol. Sci. 4: 76-79.

Van Harten AM (1998). Mutation breeding: Theory and practical applications. Cambridge University Press, Cambridge, UK.

Yadav RDS (1987). Effect of mutagens on mitotic index, seedling vigour and chlorophyll mutations in mung beam [Vigna radiata (L.) Wilczek]. J. Nuclear Agric. Biol. 16: 13-17.

Yawalkar KS (1985). Cucurbitaceous or vine crops. Vegetable crops of India Agric. Horticultural Publishing House, Nagpur, India, 150-158. 